\title{
Unmasking the face of hospitality: A postfoundational approach to a new spirituality of hospitality
}

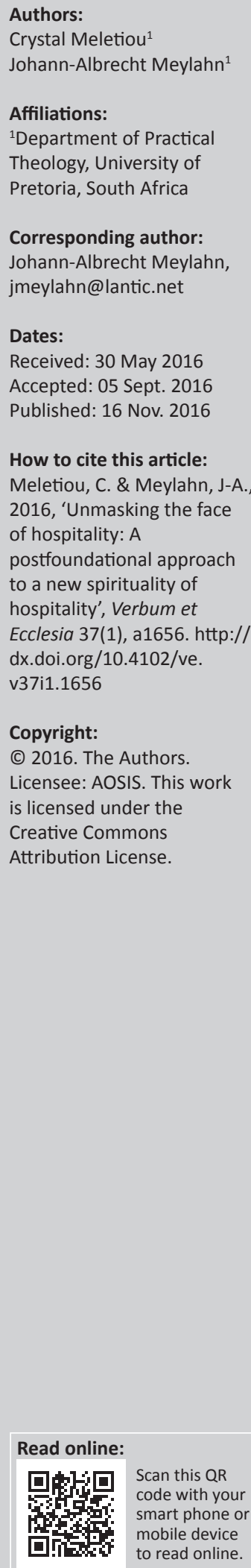

Previous research conducted on the topic of workplace spirituality seems to indicate that workers often associate spirituality in the workplace with their personal religious orientations. This article, however, presents an alternative approach to the understanding of workplace spirituality. In this article, the contemporary hospitality industry is presented as two metaphorical stage worlds, a front-stage world and a back-stage world, where actors perform the play of hospitality. Each of these worlds observes an ultimate concern: the workers of the front-stage world observe an ultimate concern of unconditional hospitality and guest satisfaction, whereas the workers of the back-stage world observe an ultimate concern of profit. Because these two worlds have opposing ultimate concerns, the current spirituality of the contemporary hospitality industry is one of dissonance and unhappiness. However, as this article will show, there is a possibility for an alternative spirituality - a spirituality of hope and endless possibilities. This spirituality will come to be through the life-giving words of the entire community. The uniqueness of the front-stage world and the back-stage world lies in their respective constructions. Some of the dominant elements that affect each of these worlds are discussed in this article. It will also be shown that the language of religion plays a role in the construction of reality. Understanding these elements is important, for only when hospitality workers recognise the elements that influence the construction of the front-stage world and the back-stage world will they be able to deconstruct and reconstruct these two worlds.

Intradisciplinary and/or interdisciplinary implications: This article presents empirical research on the spirituality of the contemporary hospitality industry. The results indicate that the current spirituality of the hospitality industry is a spirituality of dissonance and unhappiness. This research presents the prospect of a new spirituality, a spirituality of hope and endless possibilities.

\section{Introduction}

\section{Workplace spirituality: Previous findings}

Since the beginning of the new millennium, the concept of workplace spirituality has received a great deal of attention in several research papers (Bell \&Taylor 2004; Casey 2004; Driver 2005; Duchon \& Plowman 2005; Fornaciari \& Dean 2001; Fry 2003; Harter \& Buzzanell 2007; Hicks 2003; Krishnakumar \& Neck 2002; Lips-Wiersma 2003; Neal \& Biberman 2003; Sass 2000). Gotsis and Kortezi (2008:576) argue that the increased interest in workplace spirituality could be due to people's individual pursuit of higher purpose and meaning making.

Numerous scholars argue that workplace spirituality might play an imperative role in the deeper and more meaningful understanding of employee and corporate reality (Dreyer \& Dreyer 2012:1173; Gotsis \& Kortezi 2008:576; Praveen-Parboteeah \& Cullen 2003:137-151). Although some argue that workplace spirituality has a definite effect on spiritual well-being and job satisfaction (Cropanzano \& Wright 2001; Hagihara et al. 1998; Robert, Young \& Kelly 2011), others are concerned that this phenomenon might result in physical and emotional sacrifices by employees (Presser 2004:95).

Some understand workplace spirituality as the fusion of 'personal and cultural values permeating all levels of organisational life - the organisation, the team and the individual' (Gotsis \& Kortezi 2008:587). Marques (2008) puts it as follows:

Spirituality in the workplace is an experience of interconnectedness and trust among those involved in a work process, engendered by individual good-will; leading to the collective creation of a motivational

Note: This article represents a reworked version of aspects from the Ph.D. thesis of Crystal Meletiou, titled Spirituality in contemporary hospitality: A practical theological approach, in the Department of Practical Theology, University of Pretoria, with Prof. Dr JohannAlbrecht Meylahn as promoter. 
organisational culture, epitomised by reciprocity and solidarity; and resulting in enhanced overall performance, which is ultimately translated in lasting organisational excellence. (p. 24)

Garcia-Zamor $(2003: 325,326)$ is of the opinion that spiritual practices draw on 'prominent ethical theories and moral principles', and claims that 'an individual's spirituality will be a determinant factor in that person's understanding and interpretation of ethical behavior'. In this regard, Graber and Johnson (2001:39) argue that workplace spirituality should identify with the idea of 'achieving personal fulfillment or spiritual growth in the workplace'.

There are also those who understand workplace spirituality as the:

individual's perception of spiritual values present in the organisational environment, and the extent to which the work, leadership, policies, business practices and culture of the organisation fulfill the employee's spiritual needs and values. (Tombaugh, Mayfield \& Durand 2011:146)

But what determines spiritual needs and values in the workplace? In what follows, these concepts are explored from the perspectives of the front-stage and the back-stage worlds of the contemporary hospitality setting. It will be shown that workplace spirituality is not how workers incorporate their respective personal religious principles in the workplace, but rather how religion influences the construction of different working environments, hence creating different workplace spiritualities or different ultimate concerns

\section{The two worlds of the contemporary hospitality industry}

It is a common practise for hospitality workers to refer to the hotel industry as a metaphorical stage where they, the 'actors', partake in the daily 'play' of hospitality. However, like any performance arena there is a front-stage and a backstage. The workers of these two opposing stage worlds are tasked with very different duties, resulting in conflicting ultimate concerns.

\section{The front-stage world}

All guest interaction takes place in the front-stage world - a world that observes an ultimate concern of unconditional hospitality and guest satisfaction. The workers of the frontstage world typically include porters, receptionists, restaurant and bar personnel, housekeeping staff, maintenance staff and members of security.

Part of the duties of the back-stage world is to establish rules that the workers of the front-stage world need to respect in the observance of their ultimate concern, that is, unconditional hospitality and guest satisfaction. Thus, although it is required of front-stage workers to show unconditional hospitality, there are rules to be followed. These rules make unconditional hospitality impossible (Derrida 2000):

Absolute hospitality requires that I open up my home and that I give not only to the foreigner (provided with a family name, with the social status of being a foreigner, etc.), but to the absolute, unknown, anonymous other, and that I give place to them, that I let them come, that I let them arrive, and take place in the place I offer them, without asking them either reciprocity (entering into a pact) or even their names. The laws of absolute hospitality command a break with hospitality by right, with law or justice as rights. (p. 25)

Another rule that front-stage workers are expected to honour is always to show hospitality with a smile. However, in the light of the current spirituality of hospitality, a spirituality of dissonance and unhappiness, authentic kindness is not always possible. This spirituality poses tremendous emotional challenges for front-stage workers. As a result, front-stage workers put on 'happy-face masks' to create a façade of authentic happiness. Rafaeli and Sutton (1987:25) raise the concern that such constant faking of emotions may result in heightened dissonance.

Adding to the challenges that the front-stage workers face is shift work and the number of hours worked, factors that have a significant effect on the physical, psychological and emotional well-being of employees (Brymer, Perrewe \& Johns 1991; Lam \& Chen 2012; O’Neill \& Davis 2011; Pienaar \& Willemse 2008; Presser 2004; Zohar 1994).

It could be argued that the hospitality industry is not the only industry that poses these challenges for workers, yet, as this study will show, the workers of the front-stage world find it difficult to observe their ultimate concern of unconditional hospitality and guest satisfaction.

In an attempt to understand why hospitality employees find the front-stage world so emotionally challenging, it might be insightful to explore the elements that may affect the construction of this world. Meanings are understood through the conversations of numerous groups of people (Freedman \& Combs 1996:22, 23; White 1991:27, 28), where realities are constructed through a specific language and in a particular setting where specific traditions and practices are observed by a specific group of people. An example of such an environment is the front-stage world of the contemporary hospitality industry. In this world, hospitality workers speak the language of hospitality, a language that dates back to ancient biblical stories of hospitality.

In what follows, some examples of biblical, Hellenistic and cultural stories of hospitality will be discussed in an attempt to show how these stories of old influence the construction of the contemporary front-stage world.

\section{Influences of biblical stories of hospitality}

Meylahn (2009) explains that:

... the sacred texts of the Judaic-Christian tradition offer not only an understanding of the wholly otherness of God, but also form the basis of our understanding and perception of humanity (anthropology), the world and ourselves (personhood/identity). (p. 1) 
Thus, the way many people try to understand the world around them, and the role they play in it, is influenced by their association with biblical narratives and traditions.

In biblical times, hospitality was seen as a religious obligation, or, as Van Eck (2011:5) puts it, 'sacred duty'. Some of these ancient stories of hospitality are about hosts (as in the case of the front-stage workers) who are confronted with difficult decisions that could potentially expose them and their households to danger (Gn 19; Jdg 19), all in an attempt to observe an ultimate concern of unconditional hospitality.

In both the narratives of Genesis 19 and Judges 19, the hosts are required to show unconditional hospitality to their guests while under tremendous pressure. Although the hosts in these biblical stories faced the possibility of physical danger, contemporary hospitality workers are more likely to be challenged emotionally. It is during such challenging times that hospitality workers put on 'happy-face masks' to create an impression of authentic kindness. The reason for this is that as in Judeo-Christian hospitality, where it was required of the host to change the status of the visitor from stranger to guest (Malina \& Rohrbaugh 2003:369; O'Gorman 2010:56), so too is it required of contemporary hospitality workers to show unconditional hospitality to strangers.

Judeo-Christian hospitality was associated with strong ethical traditions, a concept that is still valued in contemporary hospitality. In antiquity, guests were expected to show respect to hosts and their households. It was also expected of guests to reciprocate the kindness of their hosts, typically by presenting them with gifts (Malina \& Rohrbaugh 2003:371). This concept of trading was seen as an obligation between guests and hosts (Lorencin 2008:168). Herman explains (quoted in Lorencin 2008):

Gifts beg counter-gifts, and fulfil at one and the same time a number of purposes: they repay past services, incur new obligations, and act as continuous reminders of the validity of the bond. Non-reciprocation is in this context frequently interpreted as relapse into hostility. (p. 169)

In the current era, guests usually respond to hospitality with financial reciprocation. This is where the back-stage world comes into play. One of the duties of the back-stage workers is to establish the cost at which hospitality can be shown to guests. Thus, the front-stage world, which observes an ultimate concern of unconditional hospitality and guest satisfaction, is controlled by the back-stage world, a world that observes an ultimate concern of profit.

In a way that is similar to the front-stage world's being controlled by the back-stage world, so too was Jesus controlled by the back-stage world of his time, a world that prohibited showing kindness to outsiders and castaways. Two instances where Jesus was confronted with the laws of the back-stage world of his time are the banquet in Levi's house (Mt 9:9-13; Mk 2:13-17; Lk 5:27-32) and the meal at Zacchaeus' house (Lk 19:1-10). Although it was Jesus' intention to show unconditional hospitality to all people, not everybody appreciated his 'rebellious' deeds. The Pharisees and scribes who ruled the back-stage world of antiquity saw Jesus' actions as a blasphemy against the traditions of the time (Mt 9:11; Mk 2:16; Lk 5:30). Considering the challenges that Jesus faced, it can perhaps be said that hospitality in the first century was also divided in a frontstage world, which observed an ultimate concern of unconditional hospitality and guest satisfaction, and a backstage world, in which the Pharisees and scribes determined the rules of the front-stage world.

As in the case of the stories of contemporary hospitality employees, Jesus' narrative also exposed the dominant myth of the time, that is, a myth of conditional hospitality. Because of Jesus' disrespect to this dominant myth, he had to be crucified. However, the crucifixion of Jesus provides a frame of reference for contemporary hospitality workers because Jesus' resurrection announces a new life of 'impossible possibilities there where the power of the dominating myth is broken' (Meylahn 2012:61).

Although biblical narratives might play an important role in how hospitality workers understand the front-stage world, Hellenic culture and mythology should also be considered, as these stories too might influence the construction of the front-stage world.

\section{Influences of Greek and Roman mythical stories of hospitality}

Perhaps one of the most renowned narratives of hospitality in Greek mythology is Homer's Odyssey, which tells the story of Odysseus, a respected leader during the Trojan War, whose quest was to search for hospitable reception in various situations (O'Gorman 2005:143). In his Odyssey, Homer refers to gods as well as human characters, such as Telemachus and Odysseus, who are portrayed as role models for the people of ancient Greece.

In ancient Greece, a stranger could either be a mortal human or a disguised godly being and could either be friendly or hostile (O'Gorman 2005:42). The stories of Genesis 19 and Judges 19 contain a similar understanding of a stranger. However, because it was not possible to distinguish between a god and a mortal human, it was expected of hosts to treat any strangers with the utmost respect (O'Gorman 2005:142).

In Greek mythology, the god Zeus presided over hospitality, and Jupiter was seen as the guardian of Roman hospitality laws (O'Gorman 2005:145). In Metamorphoses, Ovid tells the story of the gods Jupiter and Mercury, who were in search of shelter during their visit to earth (O'Gorman 2005:145). After they had been denied a thousand times, Jupiter and Mercury approached the simple cottage of Baucis and Philemon. The men welcomed the strangers to their humble dwelling and shared the little they had to offer, oblivious to the fact that they were entertaining gods (O'Gorman 2005:145). Later in the evening, after they had eaten, the two gods requested that their hosts accompany them to a mountain from where 
they could view the valley below. The entire valley was flooded, and there was nothing left of the homes of those who had denied Jupiter and Mercury hospitality. However, the gods were so impressed with their hosts' generosity that they transformed the meagre cottage of Baucis and Philemon into a temple where they became the priests $\left(\mathrm{O}^{\prime}\right.$ Gorman 2005:145).

The plot of this mythological story clearly resonates with the biblical narrative of Genesis 19. However, in sub-Saharan Africa, not all cultures associate with biblical and Hellenic stories of hospitality. Here, people often refer to the concept of $u b u n t u$ when they share stories of hospitality.

\section{Influences of ubuntu: A sub-Saharan understanding of hospitality}

Many African tribal societies that reside below the Sahara refer to hospitality as ubuntu (Gathogo 2008:277). The main idea of $u b u n t u$ is that all people are part of a large community (Gathogo 2008:276). Through metaphorical reference to examples of interconnectedness found in nature, ubuntu is taught to children by tribal elders through plays, music, poetry and dance (Gathogo 2008:282).

The interdependency of ubuntu is articulated in several African proverbs. Gathogo (2008:276) refers to some of the most popular Kikuyu proverbs: 'Mugogo umwe nduaraga iriuko', which means, 'On one's own, as an individual, one cannot do something substantial'; 'Mugogo umwe nduaraga iriuko', which, when translated, means, 'One log does not make a bridge'; and probably the most popular Kikuyu proverb, which states, 'Gutiri gitatuirie kingi', meaning, 'All things are interdependent'. Perhaps one of the most renowned definitions of ubuntu is that of Desmond Tutu (quoted in Mbaya 2010):

A person is a person through other persons. I would not know how to be a human being at all except (that) I learned this from other human beings. We are made for a delicate network of relationships, of interdependence. We are meant to complement each other. All kinds of things go horribly wrong when we break that fundamental Law of our being. Not even the most powerful nation can be completely self-sufficient. (p. 369)

Although some hospitality workers might relate to biblical and mythological narratives of hospitality, others might identify with the interconnectedness associated with ubuntu. Thus, African tribal practices might also affect the way in which some contemporary hospitality workers understand the front-stage world.

In this section, several influences were discussed that might affect the way in which hospitality workers understand the front-stage world, a world that observes an ultimate concern of unconditional hospitality and guest satisfaction. In a way that is similar to how these elements influence the construction of the front-stage world, there are also elements that influence the understanding of the back-stage world, a world that observes an ultimate concern of profit.

\section{The back-stage world}

Workers who work in the back-stage world typically include members of executive management and other senior administrative personnel such as accountants and marketing managers. The collective purpose of these workers is mainly to establish corporate policies and to strategise financial growth. It is very seldom that the back-stage workers interact with guests.

Earlier it was argued that biblical and mythological narratives, as well as the concept of $u b u n t u$, might influence the construction of the front-stage world. In a similar manner, there are also elements that influence the understanding of the back-stage world. Van Huyssteen (2007:5) argues that people's realities are influenced by narratives and traditions of the past. It is thus possible that the back-stage world might be influenced by the philosophies of Emile Durkheim and Max Weber (Bratton \& Denham 2014:104). These are philosophers whose thoughts had a significant influence on the understanding of capitalism. Both these philosophers were students of religion.

\section{The role of religion in the construction of reality: Durkheim}

Religion is one of the strongest forms of legitimation because if God says something, it should be considered as an ultimate truth. However, religion does not only involve God.

Religion can be understood as that which a community views as an ultimate concern. Although different communities might observe different ultimate concerns, all religions are instructive, and they each have a notion of an absolute (Durkheim 2001:26). For Jensen (2014:1), religion can be seen as a 'perplexing social and individual phenomenon' that can be 'favorably associated with agreeable human qualities such as ethics, morality and spirituality'. These qualities became prevalent in the corporate setting during the time of the Enlightenment.

Durkheim believed that society needed some religious system of joining beliefs for 'no society can exist that does not feel the need at regular intervals to sustain and reaffirm the collective feelings and ideas that constitute its unity and personality' (Durkheim 1964:322). These confirmations of ethics were regularly discussed during assemblies where individuals were able to share their thoughts. For Durkheim (1964:322), these gatherings were important because society had to realise that ' $[t]$ he ancient gods grow old or die, and others are not yet born'. However, through the collective experiences of the community, new formulae could be established that would serve humanity.

Although moral authority originates from the social groups in which people live, the group in itself controls the individual members (Durkheim 2002:3). Thus, Durkheim (2002:90) says, 'When our conscience speaks it is society speaking within us'. For Durkheim, it is imperative that people should understand the nature of morality because only when they 
understand will they be able to make sensible decisions. He explains (2002):

Now we are able to check on the extent to which the moral order is founded in the nature of things - that is in the nature of society which is to say to what extent it is what it ought to be. In the degree that we see it as such, we can freely conform to it ... Thus, on condition of having adequate knowledge of moral precepts, of their causes and of their functions, we are in a position to conform to them, but consciously and knowing why. Such conformity has nothing of constraint about it. (p. 117)

Durkheim argues that if people understand the purpose of moral obligation, they would willingly obey. A guaranteed way to establish such obedience is to urge the education system to teach modern secular morality in schools. By doing so, children will understand their roles and responsibilities in society (Bratton \& Denham 2014:218).

\section{The role of religion in the construction of reality: Weber}

Although Durkheim emphasises the role of religion as it relates to social cohesion, Weber focusses on the 'economic ethics' found in the major world religions and societies (Bratton \& Denham 2014:218). In Weber's The Protestant Ethic and the 'Spirit' of Capitalism (2002), he aspires to describe the importance of ascetic Protestantism in the development of modern capitalism in the West (Weber 2002):

The task before us is to indicate the significance of ascetic rationalism for the content of the ethic of the social economy, that is, for the type of organization and the functions of social communities, from the conventicle to the state. Then its relationship to humanist rationalism and its ideals and cultural influences, to the development of philosophical and scientific empiricism, and to technological development and the arts must be analysed ... [I]t must be shown in what way Protestant asceticism itself was influenced in its growth and character by the totality of the cultural, and especially economic, conditions of society. (pp. 121-122; italics in original)

In a nutshell, Weber proposes a new work ethic that is focussed on financial prosperity. Thus, work becomes a way of demonstrating godliness, a notion that eventually gave rise to the rationalisation of capitalism.

Weber was significantly influenced by Benjamin Franklin's work, which drew a parallel between religiosity and entrepreneurship. Weber saw Franklin's theory as the idealtype 'spirit' of capitalism (Weber 2002):

Remember, time is money. He that can earn ten shillings a day by his labour, and goes abroad, or sits idle, one half of that day, though he spends but sixpence during his diversion or idleness, ought not to reckon that the only expense; he has really spent, or rather thrown away, five shillings besides. Remember, that credit is money. If a man lets his money lie in my hands after it is due, he gives me the interest, or so much as I can make of it during that time. Remember, that money is the prolific, generating nature. Money can beget money, and its offspring can beget more, and so on. Remember this saying, the good paymaster is lord of another man's purse. He that is known to pay punctually and exactly to the time he promises, may at any time, and on any occasion, raise all the money his friends can spare. This is sometimes of great use. The most trifling actions that affect a man's credit are to be regarded. The sound of your hammer at five in the morning, or eight at night, heard by the creditors, makes him easy six months longer, but if he sees you at a billiard table, or hears your voice at the tavern, when you should be at work, he sends for his money the next day ... It shows, besides, that you are mindful of what you owe; it makes you appear a careful as well as an honest man, and that still increases your credit. (pp. 9, 10; italics in original)

Franklin's mantra clearly emphasises the duty of individuals to accumulate as much wealth as possible. For Franklin, this 'spirit' reaches further than just 'egocentric maxims' (Weber 2002:12). According to him, one's actions are established in one's religious convictions and one's quest for salvation (Weber 2002:12). Weber sums up Franklin's words as follows (Weber 2002):

The 'summum bonum' (great good) of this 'ethic' is the making of money and yet more money, coupled with a strict avoidance of all uninhibited enjoyment. Indeed, it is so completely devoid of all eudemonistic, let alone hedonist, motives, so much purely thought of as an end in itself that it appears as something wholly transcendent and irrational, beyond the 'happiness' or the 'benefit' of the individual. The aim of a man's life is indeed money making, but this is no longer merely the means to the end of satisfying the material needs of life. This reversal ... of what we might call the 'natural' state of affairs is a definite leitmotiv of capitalism, although it will always be alien to anyone who is untouched by capitalism's aura. (p. 12; italics in original)

Those who chose to follow this belief were of the opinion that material wealth was the manifestation of God's grace. This belief justified the aspiration to material achievement. Subsequently, Protestant preaching accentuated that followers had (Weber 2002):

a duty to regard themselves as elect, and to dismiss any doubts as a temptation from the devil ... The exhortation of the apostle to 'make one's calling sure' was interpreted as a duty to strive for the subjective certainty of one's election and justification in daily struggle ... And ... tireless labour in a calling was urged as the best possible means of attaining this self-assurance. This and this alone would drive away religious doubt and give assurance to one's state of grace. (p. 77; italics in original)

This philosophy, argues Weber (2002:96), gave rise to what he calls 'an ethic of inner convictions'. Eventually, with the rise of Protestantism and capitalism in the 18th century, these philosophies gained tremendous industrial support (Ashforth \& Vaidyanath 2002:362).

As time went by, the transcendental nature of work was replaced with financial greed (Lips-Wiersma, Lund Dean \& Fornaciari 2009:292). As a result, 'today's view of work and organisational form leads, at best, to a tough dilemma, and at worst to an intractable paradox when WPS [workplace spirituality] is added' (Lips-Wiersma et al. 2009:292).

In an attempt to determine to what extent the contemporary hospitality industry is influenced by the elements discussed above that might construct the front-stage world and the 
back-stage world, four hospitality employees, referred to as co-researchers, were invited to participate in this postfoundational ${ }^{1}$ qualitative empirical study.

\section{Methodology}

This empirical study relied on the method of narrative inquiry. Because people are all born into stories, their social and historical frameworks continuously invite them to reflect on narratives regarding specific traditions and events (Freedman \& Combs 1996:42). For this reason, it can be argued that it is also by reflecting on stories, such as the ancient stories of hospitality, that contemporary hospitality workers understand their working environments.

The purpose of narrative inquiry is to attempt to co-construct meanings through the process of 'storying and re-storying in order to reveal multidimensional meanings and present an authentic and compelling rendering of the data' (Leavy 2015:46). Although narrative inquiry relies on small sample sizes, it produces rich case studies (Leavy 2015:46). Thus, narrative inquiry is not concerned with the quantity of data, but rather with the richness of the multiple possible interpretations of experiences.

For Meylahn (2012:56-63), the process of narrative inquiry can be associated with a metaphorical dance. He (2012:56-63) explains that the dance of narrative inquiry consists of five movements: listening, interpreting, discerning, poetry and embracing. These circular and repetitive dance movements continuously encourage the researcher to consider and re-consider the different layers of the narratives. Eventually, through the repetitive movements of this dance, dominant and shadow stories emerge. As the conversation develops, all the stories are woven together into an intriguing tapestry (Moen 2006:56).

\section{Movement one: Listening}

First layer narratives, explains Meylahn (2012:57), are usually freely shared. This layer of narratives typically emerges from the common shared language of a community, 'which tells of the norms, values, histories and dominant themes of a community' (Meylahn 2012:57). By carefully listening to the dominant language, the researcher can identify the religion of the particular world or, put differently, the ultimate concern. However, there is never only one language. There is always multiplicity. For this reason, the researcher needs to pay attention to the alternative stories, particularly to the shadow stories that are usually 'suppressed, excluded, ignored and marginalised, but question the dominant common language of the particular context' (Meylahn 2014:5).

1.Swinton and Mowat (2006:452) explain postfoundationalism as follows: ${ }^{\prime} . .$. all human practices are historically grounded and inherently value-laden. Practices such as prayer, hospitality and friendship contain their own particular theoctices such as prayer, hospitality and friendship contain their own particular theological meanings, social and theological histories, implicit and explicit norms and mora expectations. The ways in which we practice and the forms of practice in which we participate are therefore filled with deep meaning, purpose and direction. Put slightly differently, the forms of practice that we participate in are theory-laden Thus, the way people make sense of the world around them is influenced by history, religion and culture.

\section{Movement two: Interpreting}

Narratives need to be interpreted, and to do so, it is important to place stories in their specific narrative settings (Meylahn 2012:58). For example, in the case of the co-researchers who participated in this study, the narratives need to be interpreted within the context of the contemporary hospitality setting where two worlds exist.

During the interview process, the co-researchers told dominant stories about the front-stage world and the backstage world. The dominant stories of the front-stage world (which observes an ultimate concern of unconditional hospitality and guest satisfaction) spoke of the desire for and the importance of respect, understanding, gratitude and integrity. The dominant stories of the back-stage world (which observes an ultimate concern of profit) told of being bullied into working extra hours and of cost saving, disrespect, subordination, belittlement and unfairness.

The dominant stories of the front-stage and back-stage worlds stand in direct contrast to each other. The reason for this difference, explains Meylahn (2012:59), lies in the common cultural language (regilare) of these communities. For example, in the light of the two groups' distinct ultimate concerns, the workers of the front-stage world speak a very different language from the workers of the back-stage world. Thus, the binding power of the specific obligations in each of these communities legitimises and justifies the behaviour of the community members as they express their obligation to their collective good (Meylahn 2012:59).

In addition to the dominant stories, there are also shadow stories. According to the dominant stories, shadow stories should not exist, but they do (Meylahn 2014:6). These shadow stories disturb the dominant stories because they question the authority of the dominant myth (Meylahn 2014:6) of unconditional hospitality. An example of such a story, according to Meylahn (2014:6), is the story of Christ, which also challenged the dominant myth and authority of the Pharisees.

In this regard, Meylahn (2014:6) argues, practical theologians, like Christ, need to risk being blasphemous, as they too challenge the dominant myth - in this case, the myth of unconditional hospitality as well as the myth of profit. However, by following Christ into the incarnation and crucifixion, the practical theologian 'witnesses the autodeconstruction of the gods' (Meylahn 2014:7; italics in original) in this case, the gods of the front-stage world and the back-stage world. Through this auto-deconstruction, a new community is resurrected and liberated from the dominant myths. Yet this new community is not the ultimate community, for, in its resurrection, a new dominant story will emerge that in itself excludes and creates shadow stories that will then need to be deconstructed.

In this study, the hospitality industry is seen as a stage where actors perform their daily routines. This metaphorical reference to the hospitality industry inspired the researcher to 
interpret the narratives of the co-researchers in a creative way. Through the collaboration with actors and a production team, I produced a film, Behind the Mask of Hospitality (YouTube 2015). Once the production of the film was completed, the co-researchers were asked to share their thoughts of the film. ${ }^{2}$ The following are some of their responses:

I could definitely relate to the emotions of the characters and I feel that anyone who has been in the industry, or still is, would be able to relate to the characters and their situations. In my opinion, 'the mask' is always on and at times one forgets to take it off, or worse, it becomes a permanent facial feature. And that is when it starts to affect one's private life. (Alex, male, mid-forties, senior management)

I could definitely relate to the character of the concierge, having worked as one. The part of coming home and having those few moments with your wife and child brought back painful memories. The one picture that really hit hard was the closing moments of the film with the washed, but stained, shirt hanging ready for the next day's wear. It re-enforced the point that you may try and wash out the effects of the emotional trauma you experience, but it will leave a lasting scar (stain). (David, male, mid-forties, senior management)

The video portrayed everything perfectly. It has been a source of motivation for me as a manager and employee at the same time. (Cindy, female, early thirties, middle-management)

I must admit, the first time I watched the video it seemed a bit strange, almost like looking in a mirror but not really recognising what you are seeing. The second time it became so clear that the emotions portrayed in the film was exactly how it was in hospitality. Continuously ensuring that others' needs are put before your own and that your loved ones have to accept second best. (John, male, late twenties, junior management)

Many of the themes that are portrayed in the film have also been pinpointed by previous research, which indicates that occupational stress affects the private lives of employees, causing problems in marriages, friendships and communities (Kahn \& Byosiere 1992; Mulvaney et al. 2007). Shift work has also been associated with marital conflict and child-related problems, as has work schedules that involve public holidays and weekends (Almeida 2004:127).

To incorporate art in research does not imply an ultimate interpretation but rather creates the possibility of alternative interpretations. Art also crosses language barriers. Leavy (2015:1) notes that academic articles are 'sterile, jargon-filled and formulaic'. In an attempt to 'revitalise' her academic research, Leavy started to incorporate art in her studies. Although some scholars might find the use of art a rather unfamiliar methodology, others argue that it can play a valuable role in research (Chenail 2008:10).

\section{Movement three: Discerning}

In this step, from the cracks in the dominant common language of the community, the narratives of the co-researchers are discerned as ultimate myths or beliefs (Meylahn 2012:60).
These myths result in many victims. In the case of this study, the victims were the workers of the front-stage world.

During this movement, it is the responsibility of the practical theologian to identify the various divinities that the co-researchers consider as their absolute concerns. The engagement with these ultimate myths or 'gods of the contexts' is crucial to understand the lived religions of the coresearchers (Meylahn 2014:6). The purpose, however, is not to judge these divinities but rather to respectfully recognise that each situation has its gods (Meylahn 2014:6).

\section{Movement four: Poetry (re-authoring)}

This movement begins with the movement of discernment (Meylahn 2014:6). Here Meylahn (2012:61) highlights the Christ narrative, which offers a frame of reference through which people can understand the world. Christ's crucifixion is a tale of a criminal who was crucified because he was disrespectful to the dominant myth of the time. However, after 3 days, Jesus rose from the dead, announcing a new life of 'impossible possibilities there where the power of the dominating myth is broken' (Meylahn 2012:61).

It is important that the story of Christ should be declared in the context of the cracks that exist in the stories of the dominant myth and that the resurrection should be seen as the prospect of new possibilities previously impossible under the dominant myth (Meylahn 2012:61). This identification with the Christ narrative, explains Meylahn (2012:61), is enabled and encouraged by the 'hope of the kingdom still to come', inviting people to 'follow Christ into the cracks of the community'.

\section{Movement five: Embracing (a never-ending dance)}

During this dance movement, new life-giving words come into being, encouraged by the association with the Triune God (Meylahn 2012:62). These life-giving words are filled with impossible possibilities of transformation, liberated from the power and death of the dominating myths (Meylahn 2012:62). This new space with its impossible possibilities needs to be embraced and lived in to the full because once the minds of both front-stage and back-stage workers have been liberated from their respective dominant myths, new ideas will emerge within the community (Meylahn 2012:62). As time goes by, this new life will transform into 'correct practices' and, as a result, these practices will be endorsed by a new dominant story. However, this new story will also have shadow stories and that is why it is a dance without an end (Meylahn 2012:63).

Besides the dominant stories and the shadow stories, the coresearchers also discussed certain themes. These included incidents of bullying, subordination and disrespect. If the contemporary hospitality industry is interested in resolving the differences that currently exist between the front-stage world and the back-stage world, it is important to address matters that might jeopardise the process of reconciliation. 


\section{The importance of leadership styles in the contemporary hospitality industry}

Leadership style in the hospitality industry is a matter of tremendous importance because not only is the hospitality industry one of the fastest developing industries in the 21st century (Holjevac 2003:130), it is also a people-centred industry that is renowned for its labour intensity (Pittaway, Carmouche \& Chell 1998:408). According to the narratives of the co-researchers, ${ }^{3}$ there are some back-stage workers who behave uncivilly towards some workers of the front-stage world. Such acts of incivility result in tremendous emotional challenges for those who are victimised. Namie (2003) refers to such emotional abuse as corporate bullying and defines this phenomenon as follows:

'status-blind' interpersonal hostility that is deliberate, repeated and sufficiently severe as to harm the targeted person's health or economic status. Further, it is driven by perpetrators' need to control another individual, often undermining legitimate business interests in the process. (p. 1)

In a study conducted by Azulay, Park and Wickham (quoted in Crampton \& Hodge 2008:1), it was shown that bosses were the primary instigators of offensive conduct. Although workplace incivility is unacceptable, this phenomenon receives considerably less attention than workplace violence or harassment (Crampton \& Hodge 2008:3). A study conducted by Clark, Harline and Jones (2008:1) shows that the leadership styles of executives have a tremendous influence on the behaviour and dedication of employees. Crampton and Hodge (2008:2) identify the following four ways in which rudeness affects employee activity:

- Employees waste time worrying about the uncivil incident or future interactions with the instigators, and try to avoid the instigators.

- Employees become less committed.

- Employees do not involve themselves in tasks beyond the borders of their job specification and expend less effort to meet their responsibilities.

- Employees are less willing to help others, and they reduce their contribution to the organisation.

According to Clark et al. (2008:1), the importance of frontline staff and the service that these workers provide 'cannot be overstated' because they are directly responsible for 'face-to-face customer service, service quality, and customer satisfaction'. Clark et al. $(2008: 16,17)$ also point out that effective leadership increases the extent to which values are shared between establishments and their employees. However, this suggests that hotel managers have to show 'personal commitment to serving customers' and that they should be able to convey their expectations in a civil manner (Clark et al. 2008:17).

3.All the co-researchers held managerial positions in the front-stage world. Their experiences were not based only on their current employment, but on thei collective experiences throughout their careers as hoteliers.
There are, nevertheless, managers who rely on fear to control employees. According to Fry (2003:699), leaders rely on fear to create a 'control system that ensures minimum levels of effort, organizational commitment, and performance'. However, fear is emotionally destructive and results in feelings of 'powerlessness and low confidence, low commitment, enthusiasm, and imagination' (Fry 2003:699). Fear also leads to feelings of reduced trust and communication, and as a result, important issues are hidden or suppressed (Fry 2003:699).

Although acts of mistreatment might have a devastating effect on employees, transformational leadership can 'improve employee dedications, social behavior, role clarity, and satisfaction, while also reducing the effects of job stress and burnout' (Clark et al. 2008:2). Leadership evidently plays a pivotal role in organisational development and employee contentment. Perhaps the time has come for organisations to address incidents of incivility with greater urgency, for only when there is mutual respect can there be coherence amongst the workforce.

\section{Conclusion}

\section{An alternative preferred spirituality of hope and grace}

Hospitality can be seen as a colourful work of art, a multidimensional masterpiece painted on the canvas of human history and framed by religious, mythological, social and traditional principles. However, how this painting is interpreted depends on the stories, fables and traditions that make up the social construction of people's knowledge, and the significance this construction has for them within this social-cultural-religious context.

This article has argued that the contemporary hospitality industry consists of two worlds, namely a front-stage world and a back-stage world. Those who work in the front-stage world observe an ultimate concern of unconditional hospitality and guest satisfaction, whereas the workers of the back-stage world observe an ultimate concern of profit. The conflict that exists between these two worlds is the cause of the current spirituality in the contemporary hospitality industry: a spirituality of dissonance and unhappiness.

However, this spirituality can be altered. If the entire community, both the front-stage world and the back-stage world, can engage in dialogue, the narratives of the community will auto-deconstruct the ultimate myths. This 'crucifixion' of the ultimate myths will lead to the resurrection of a new spirituality: a spirituality of hope and grace. This new spirituality will arise through the life-giving words of the community.

This new spirituality will be one of impossible possibilities. However, it will not be the ultimate spirituality because it will develop its own new dominant stories in time, and therefore, through the cracks in these new stories, shadow 
stories will again appear that will challenge the dominant myth of the new community. Thus, this new spirituality will be ever-changing, always depending on the life-giving words of the community to keep it alive.

\section{Acknowledgements Competing interests}

The authors declare that they have no financial or personal relationships which may have inappropriately influenced them in writing this article.

\section{Authors' contributions}

C.M. is the author of the article. J-A.M. was the supervisor during the PhD studies of C.M.

\section{References}

Almeida, D.M., 2004, 'Using daily diaries to assess temporal frictions between work and family', in A.C. Crouter \& A. Booth (eds.), Work-family challenges for low income parents and their children, pp. 127-136, Lawrence Erlbaum, Mahwah, NJ.

Ashforth, B.E. \& Vaidyanath, D., 2002, 'Work organizations as secular religions', Journal of Management Inquiry11(4),359-370. http://dx.doi.org/10.1177/1056492602238843

Bell, E. \& Taylor, S., 2004, 'From outward bound to inward bound: The prophetic voices and discursive practices of spiritual management development', Human Relations 57(4), 439-466. http://dx.doi.org/10.1177/0018726704043895

Bratton, J. \& Denham, D., 2014, Capitalism and classical social theory, 2nd edn., University of Toronto Press, Toronto, ON.

Brymer, R.A., Perrewe, P.L. \& Johns, T.R., 1991, 'Managerial job stress in the hotel industry', International Journal of Hospitality Management 10(1), 47-58. http:// dx.doi.org/10.1016/0278-4319(91)90006-4

Casey, C., 2004, 'Bureaucracy re-enchanted? Spirit, experts and authority in organizations', Organization 11(1), 59-79. http://dx.doi.org/10.1177/1350508 404039658

Chenail, R.J., 2008, “"But is it research?”: A review of Patricia Leavy's method meets art: Arts-based research practice', The Weekly Qualitative Report 1(2), 7-12.

Clark, R.A., Hartline, M.D. \& Jones, K.C., 2008, 'The effects of leadership style on hotel employees' commitment to service quality', Cornell Hospitality Quarterly 50(2) 209-231. http://dx.doi.org/10.1177/1938965508315371

Crampton, S.M. \& Hodge, J.W., 2008, 'Rudeness and incivility in the workplace', Journal of Leadership, Accountability and Ethics 1-8, viewed 25 Novermber 2015 from http://www.na-businesspress.com/JLAE/crampton.pdf

Cropanzano, C.K. \& Wright, T.A., 2001, 'When a "happy" worker is really a "productive" worker: A review and further refinement of the happy-productive worker thesis', Consulting Psychology Journal: Practice \& Research 53(3), 182-199. http://dx.doi. org/10.1037/1061-4087.53.3.182

Derrida, J., 2000, Of hospitality, Stanford University Press, Stanford, CA.

Dreyer, L.I. \& Dreyer, S., 2012, 'Religious involvement, psychosocial resourcefulness, and health', Journal of Religion and Health 51(4), 1172-1187. http://dx.doi. org/10.1007/s10943-010-9423-y

Driver, M., 2005, 'From empty speech to full speech? Reconceptualizing spirituality in organizations based on a psychoanalytically-grounded understanding of the self', Human Relations 58(9), 1091-1110. http://dx.doi.org/10.1177/001872670 5059038

Duchon, D. \& Plowman, D.A., 2005, 'Nurturing the spirit at work: Impact on work unit performance', The Leadership Quarterly 16(5), 807-833. http://dx.doi.org/ 10.1016/j.leaqua.2005.07.008

Durkheim, É., 1964, The division of labor in society, Free Press, New York.

Durkheim, É., 2001, The elementary forms of religious life, Oxford University Press, New York.

Durkheim, É., 2002, Moral educations, The Free Press, New York.

Fornaciari, C.J. \& Dean, K.L., 2001, 'Making the quantum leap', Journal of Organizational Change Management 14(4), 335-351. http://dx.doi.org/10.1108/ EUM000000000554

Freedman, J. \& Combs, G., 1996, Narrative therapy: The social construction of preferred realities, 1st edn., W.W. Norton Company, New York.

Fry, L.W., 2003, 'Toward a theory of spiritual leadership', The Leadership Quarterly 14(6), 693-727. http://dx.doi.org/10.1016/j.leaqua.2003.09.001

Garcia-Zamor, J.-C., 2003, 'Workplace spirituality in the United States and the former East Germany', in R.A. Giacalone \& C.L. Jurkiewicz (eds.), Handbook of workplace spirituality and organizational performance, 2nd edn., pp. 314-335, Routledge, New York.

Gathogo, J.M., 2008, 'Some expressions of African hospitality today', Scriptura International Journal of Bible, Religion and Theology in Southern Africa 99, 275-287
Gotsis, G. \& Kortezi, Z., 2008, 'Philosophical foundations of workplace spirituality: A critical approach', Journal of Business Ethics 78(4), 575-600. http://dx.doi. critical approach', Journal of Bus
org/10.1007/s10551-007-9369-5

Graber, D.R. \& Johnson, J.A., 2001, 'Spirituality and healthcare organizations', Journal Healthcare management 46(1), 39-50.

Hagihara, A., Tarumi, K., Babazono, A., Nobutomo, K. \& Morimoto, K., 1998, 'Work versus non-work predictors of job satisfaction among Japanese white-colla workers', Journal of Occupational Health 40(4), 285-292. http://dx.doi.org/ 10.1539/joh.40.285

Harter, L. \& Buzzanell, P., 2007, '(Re)storying organizational communication theory and practice: Continuing the conversation about spirituality and work', Communication Studies 58(3), 223-226. http://dx.doi.org/10.1080/10510970701518322

Hicks, D.A., 2003, Religion and the workplace pluralism, spirituality, leadership, Cambridge University Press, Cambridge.

Holjevac, I.A., 2003, 'A vision of tourism and the hotel industry in the 21st century', Hospitality Management 22(2), 129-134. http://dx.doi.org/10.1016/S02784319(03)00021-5

Jensen, J.J., 2014, What is religion?, Routledge, New York.

Kahn, R.L. \& Byosiere, P., 1992, 'Stress in organizations', in M.D. Dunnette \& L.M. Hough (eds.), Handbook of industrial and organizational psychology, 2nd edn., pp. 571-648, Rand McNally, Chicago, IL.

Krishnakumar, S. \& Neck, C.P., 2002, 'The "what" "why" and "how" of spirituality in the workplace', Journal of Managerial Psychology 17(3), 153-164. http://dx.doi. org/10.1108/02683940210423060

Lam, W. \& Chen, Z., 2012, 'When I put on my service mask: Determinants and outcomes of emotional labour among hotel service providers according to effective event theory', International Journal of Hospitality Management 31(1), 3-11. http://dx.doi.org/10.1016/j.ijhm.2011.04.009

Leavy, P., 2015, Method meets art: Arts-based research practice, 2nd edn., Guilford Press, New York.

Lips-Wiersma, M., 2003, 'Making conscious choices in doing research on workplace spirituality utilizing the "Holistic Development Model" to articulate values, assumptions and dogmas of the knower', Journal of Organizational Change Management 16(4), 406-425. http://dx.doi.org/10.1108/09534810310484163

Lips-Wiersma, M., Lund Dean, K. \& Fornaciari, C.J., 2009, 'Theorizing the dark side of the workplace spirituality movement', Journal of Management Inquiry 18(4), 288-300. http://dx.doi.org/10.1177/1056492609339017

Lorencin, I., 2008, 'Hospitality versus patronage: An investigation of social dynamics in the third epistle of John', Andrews University Seminary Studies 46(2), 165-174.

Malina, B.J. \& Rohrbaugh, R.L., 2003, Social-science commentary on the Synoptic Gospels, 2nd edn., Fortress Press, Minneapolis, MN.

Marques, J., 2008, 'Spirituality at work: Internal growth with potential external challenges', Journal for Quality and Participation 31(3), 24-27.

Mbaya, H., 2010, 'Social capital and the imperatives of the concept and life of Ubuntu in the South African context', Scriptoria: International Journal of Bible, Religion and Theology in Southern Africa 104, 367-376.

Meylahn, J.-A., 2009, 'Responsibility, God and society: The cry of the other in the sacred texts as a challenge towards responsible global citizenship', HTS Theology Studies 65(1), Art. \#131, 1-5.

Meylahn, J.-A., 2012, Church emerging from the cracks: A church IN, but not OF the world, Sun Media, Bloemfontein.

Meylahn, J.-A., 2014, “"My city of ruins": A city to come', HTS Theological Studies 70(3), Art. \#2723, 1-6.

Moen, T., 2006, 'Reflections on the narrative research approach', Internationa Institute for Qualitative methodology (IIQM) 5(4), 56-69.

Mulvaney, R.H., O'Neill, J.W., Cleveland, J.N. \& Crouter, A.C., 2007, 'A model of workfamily dynamics for hotel managers', Annals of Tourism Research 34(1), 66-87. $\mathrm{http} / / /$ dx.doi.org/10.1016/j.annals.2006.07.002

Namie, G., 2003, 'Workplace bullying: Escalated incivility', Ivey Business Journal 1-7, viewed 11 October 2015, from http://www.rit.edu/ ${ }^{2}$ w-aaup/documents_not_rit/ ivey_workplace_bulling.pdf

Neal, J. \& Biberman, J., 2003, 'Introduction: The leading edge in research on spirituality and organisations', Journal of Organizational Change Management 16(4), 363-366. $\mathrm{http} / / / \mathrm{dx}$.doi.org/10.1108/09534810310484127

O'Gorman, K.D., 2005, 'Modern hospitality: Lessons from the past', Journal of Hospitality and Tourism Management 12(2), 141-151.

O'Gorman, K.D., 2010, The origins of hospitality and tourism, Goodfellow Publishers, Oxford.

O'Neill, J.W. \& Davis, K., 2011, 'Work stress and well-being in the hotel industry', International Journal of Hospitality Management 30(2), 385-390. http://dx.doi. org/10.1016/j.ijhm.2010.07.007

Pienaar, J. \& Willemse, S., 2008, 'Burnout engagement, coping and general health of service employees in the hospitality industry', Tourism Management 29(6), 1053-1063. http://dx.doi.org/10.1016/j.tourman.2008.01.006

Pittaway, L., Carmouche, R. \& Chell, E., 1998, 'The way forward: Leadership research in the hospitality industry', Hospitality Management 17(4), 407-426. http://dx. doi.org/10.1016/S0278-4319(98)00035-8

Praveen-Parboteeah, K. \& Cullen, J.B., 2003, 'Ethical climates and spirituality: An exploratory examination of theoretical links', in R.A. Giacalone \& C.L. Jurkiewicz (eds.), Handbook of workplace spirituality and organizational performance, 2 nd edn., pp. 137-151, Routledge, New York. 
Presser, H.B., 2004, 'Employment in a 24/7 economy: Challenges for the family', in A.C. Crouter \& A. Booth (eds.), Work-family challenges for low-income parents and their children, pp. 83-106, Lawrence Erlbaum, Mahwah.

Rafaeli, A. \& Sutton, R., 1987, 'Expression of emotion as part of the work role', Academy of Management Journal 1(1), 23-37.

Robert, T.E., Young, J.S. \& Kelly, V.A., 2011, 'Relationships between adult workers' spiritual wellbeing and job satisfaction: A preliminary study', Counseling and Values 50(3), 165-175. http://dx.doi.org/10.1002/j.2161-007X.2006.tb00053.x

Sass, J.S., 2000, 'Characterizing organizational spirituality: An organizational communication culture approach', Communication Studies 51(3), 195-217. http://dx.doi.org/10.1080/10510970009388520

Tombaugh, J.R., Mayfield, C. \& Durand, R., 2011, 'Spiritual expression at work: Exploring the active voice of workplace spirituality', International Journal of Organizationa Analysis 19(2), 146-170. http://dx.doi.org/10.1108/19348831111135083
Van Eck, E., 2011, 'When neighbours are not neighbours: A social scientific reading of the parable of the friend at midnight (Lk 11:5-8)', HTS Theological Studies 67(1), Art. \#788, 1-14.

Van Huyssteen, J.W., 2007, A brief overview of a theologian's journey to interdisciplinarity, Theological Seminary, Princeton, NJ.

Weber, M., 2002, The protestant ethic and the "Spirit" of capitalism, Penguin Group, New York.

White, M., 1991, 'Deconstruction and therapy', Dulwich Centre Newsletter 3, 21-40.

YouTube, 2015, Behind the mask of hospitality, viewed n.d., from https://www. youtube.com/watch?v=n2gpwBDMDpk

Zohar, D., 1994, 'Analysis of job stress profile in the hotel industry', Internationa Journal of Hospitality Management 13(3), 219-231. http://dx.doi.org/10.1016/ 0278-4319(94)90022-1 